\title{
PERBANDINGAN PERLAKUAN PAJAK PENGHASILAN UNTUK DOKTER DENGAN STATUS PEGAWAI NEGERI DAN DOKTER DENGAN STATUS PEGAWAI SWASTA
}

\author{
(Studi Kasus Pada dr. N dan dr. S)
}

\author{
Rizki Alaika \\ Program Studi Magister Akuntansi, Fakultas Ekonomi dan Bisnis, \\ Universitas Padjadjaran, Bandung, Indonesia. \\ Email: rizkialaika@gmail.com
}

\begin{abstract}
This study aims to analyze the imposition of Income Tax for doctors with civil servant status or private employees and analyze whether there are similarities and differences in the imposition of Income Taxes between doctors with civil servant status or private employees. Data used by researchers, namely primary data and secondary data. The research method used is descriptive research method. The results of the study show that domestic individual taxpayers who are doctors with status as civil servants or private employees can be subject to final income tax, not final, or not subject to income tax on income earned. There are similarities and differences in the imposition of income tax between domestic individual taxpayers who are doctors with status as civil servants and private employees.
\end{abstract}

Keywords: income tax, doctor, public servant, private employee, tax payer, independent personal service, liberal professional service.

\begin{abstract}
Abstrak
Penelitian ini bertujuan untuk menganalisis pengenaan Pajak Penghasilan untuk dokter dengan status pegawai negeri atau pegawai swasta serta menganalisis apakah terdapat persamaan dan perbedaan pengenaan Pajak Penghasilan antara dokter dengan status pegawai negeri atau pegawai swasta. Data yang digunakan oleh peneliti, yaitu data primer dan data sekunder. Metode penelitian yang digunakan adalah metode penelitian deskriptif. Hasil penelitian menunjukkan
\end{abstract}


bahwa, Wajib Pajak orang pribadi dalam negeri yang berprofesi dokter dengan status sebagai pegawai negeri atau pegawai swasta dapat dikenakan Pajak Penghasilan yang bersifat final, tidak final, maupun tidak dikenakan Pajak Penghasilan atas penghasilan yang diperolehnya. Terdapat persamaan dan perbedaan pengenaan pajak penghasilan antara Wajib Pajak orang pribadi dalam negeri yang berprofesi dokter dengan status sebagai pegawai negeri dan pegawai swasta.

Kata kunci: pajak penghasilan, dokter, pegawai negeri, pegawai swasta, wajib pajak, pekerjaan bebas, tenaga ahli.

\section{PENDAHULUAN}

Pada tahun 2018, penerimaan perpajakan di Indonesia mencapai 78,14\% dari jumlah pendapatan negara (Laporan Keuangan Pemerintah Pusat Tahun 2018, 2019:79). Penerimaan Pajak Penghasilan ( $\mathrm{PPh}$ ) memiliki proporsi terbesar dalam penerimaan perpajakan di Indonesia, yaitu 49,38\% (Laporan Keuangan Pemerintah Pusat Tahun 2018, 2019:38). Di Indonesia, PPh merupakan salah satu pajak yang menggunakan sistem pemungutan pajak self assessment system. Tahun 1967 sudah diperkenalkan self assessment system ini, tetapi dibatasi hanya dalam hal menghitung pajak (Meliala dan Oetomo, 2012:11). Namun, sejak reformasi perpajakan 1983 mulai berlaku self assessment system yang tidak hanya melakukan perhitungan pajak, melainkan Wajib Pajak aktif harus menghitung sendiri jumlah pajak yang terutang, membayar pajak yang terutang tersebut, kemudian mengisi dan melaporkan Surat Pemberitahuan, sedangkan petugas perpajakan hanya mengawasi dan membimbing Wajib Pajak. Wajib Pajak melakukan kewajiban pajak tersebut harus sesuai dengan peraturan pajak yang berlaku. Karena semakin tinggi tingkat pemahaman wajib pajak mengenai peraturan pajak maka tingkat kepatuhan wajib pajak dalam memenuhi kewajiban perpajakannya juga akan semakin tinggi (Rizki dan Bani, 2018). Sehingga wajib pajak diharapkan mampu memahami dan mengimplementasikan peraturan pajak yang berlaku meskipun tidak memiliki latar belakang pendidikan terkait bidang perpajakan atau bukan berprofesi dalam bidang pajak.

Beberapa profesi yang mungkin tidak memiliki latar belakang pendidikan terkait bidang perpajakan atau bukan berprofesi dalam bidang pajak, misalnya dokter, arsitek, seniman, dan olahragawan. Hasil wawancara dengan beberapa dokter adalah sebagian besar dokter tidak memahami peraturan pajak. Padahal dokter dapat memperoleh penghasilan dengan melakukan praktik kedokteran, juga dapat menjadi narasumber dalam seminar, tenaga pendidik, peserta kegiatan atau perlombaan, melakukan usaha bisnis baik dalam bidang kesehatan maupun bidang non kesehatan, dan kegiatan lainnya. Dari setiap kegiatan yang dilakukan dokter, 
maka dapat memperoleh beberapa jenis penghasilan. Selain kegiatan tersebut, dokter juga dapat memperoleh penghasilan lainnya seperti hadiah, komisi, bunga, dividen, dan sebagainya. Sehingga, dokter merupakan salah satu profesi yang berpotensi untuk dikenakan $\mathrm{PPh}$.

Atas penghasilan yang diperoleh dokter tersebut, maka dokter dituntut untuk memenuhi kewajiban atas PPh dalam menghitung, menyetor atau melunasi, serta melaporkan atas PPh, meskipun mungkin berbeda perlakuan PPhnya untuk setiap jenis penghasilan tersebut. Selain berdasarkan jenis penghasilan, perbedaan perlakuan PPh mungkin juga dapat terjadi akibat perbedaan jenis status dokter, misalnya dokter dengan status sebagai pegawai negeri atau dokter dengan status sebagai pegawai swasta.

Berdasarkan latar belakang di atas, maka rumusan masalah dalam penelitian ini antara lain: (1) Bagaimana perlakuan PPh atas berbagai jenis penghasilan yang diperoleh dokter dengan status sebagai pegawai negeri atau pegawai swasta?; (2) Bagaimana pengenaan PPh bagi dr. N dan dr. S pada tahun pajak 2018?; (3) Apa saja persamaan dan perbedaan perlakuan $\mathrm{PPh}$ antara dokter dengan status sebagai pegawai negeri dan dokter dengan status sebagai pegawai swasta? Sedangkan tujuan penelitian, yaitu: (1) Mengetahui perlakuan $\mathrm{PPh}$ atas berbagai jenis penghasilan yang diperoleh dokter dengan status sebagai pegawai negeri atau pegawai swasta; (2) Mengetahui pengenaan PPh bagi dr. $\mathrm{N}$ dan dr. S pada tahun pajak 2018; (3) Mengidentifikasi persamaan dan perbedaan perlakuan $\mathrm{PPh}$ antara dokter dengan status sebagai pegawai negeri dan dokter dengan status sebagai pegawai swasta. Sehingga manfaat penelitian ini diharapkan dapat memberikan informasi dan pengetahuan mengenai perlakuan $\mathrm{PPh}$ atas penghasilan yang diperoleh dokter dengan status sebagai pegawai negeri atau pegawai swasta. Sehingga dapat membantu dokter memenuhi hak dan kewajiban atas PPhnya sesuai dengan peraturan perpajakan yang berlaku.

\section{KERANGKA PEMIKIRAN}

Menurut Mardiasmo (2018:7), PPh memiliki sifat pajak subjektif, yaitu pajak yang berpangkal atau berdasarkan pada subjeknya, dalam arti memerhatikan keadaan diri Wajib Pajak. Orang pribadi merupakan salah satu yang termasuk dalam subjek pajak. Penghasilan yang diperoleh orang pribadi dapat bersumber dari manapun. Subjek pajak orang pribadi dalam negeri menjadi Wajib Pajak apabila telah menerima penghasilan yang besarnya melebihi Penghasilan Tidak Kena Pajak (Mardiasmo, 2018:154). Besarnya PTKP untuk Wajib Pajak orang pribadi diatur dalam PMK No. 101/PMK.010/2016. Maka, PPh orang pribadi adalah PPh yang ditujukan kepada orang pribadi sebagai subjek pajaknya, 
kemudian melihat penghasilan sebagai objek yang dimiliki oleh orang pribadi tersebut apakah termasuk objek pajak berdasarkan UU PPh.

Dalam penjelasan Pasal 4 ayat (1) UU PPh menyebutkan bahwa, dilihat dari mengalirnya tambahan kemampuan ekonomis kepada Wajib Pajak, penghasilan dapat dikategorikan menjadi: (i) penghasilan dari pekerjaan dalam hubungan kerja dan pekerjaan bebas seperti gaji, honorarium, penghasilan dari praktik dokter, akuntan, notaris, pengacara, aktuaris, dan sebagainya; (ii) penghasilan dari usaha dan kegiatan; (iii) penghasilan dari modal yang berupa harta gerak ataupun harta tak gerak, seperti sewa, bunga, dividen, royalti, dan keuntungan penjualan harta atau hak yang tidak dipergunakan untuk usaha; dan (iv) penghasilan lain-lain, seperti pembebasan utang, hadiah, hibah, dan warisan. UU PPh memiliki aturan yang berbeda dalam perlakuan pajak atas setiap kategori penghasilan tersebut. Selain itu, perlakuan pajak juga dapat berbeda meskipun penghasilan dalam kategori yang sama.

Seperti yang telah disebutkan dalam kategori penghasilan, salah satu profesi orang pribadi yang mendapatkan penghasilan dari pekerjaan bebas adalah dokter. Dalam UU No. 36 Tahun 2014 tentang tenaga kesehatan Pasal 11 ayat (2) menyebutkan bahwa dokter, dokter gigi, dokter spesialis, dan dokter gigi spesialis merupakan jenis tenaga kesehatan yang termasuk dalam kelompok tenaga medis. Dokter dapat memperoleh penghasilan yang terkait dengan profesi dokter atau diluar profesi dokter. Penghasilan yang terkait dengan profesi dokter, disesuaikan dengan ketetapan dalam Surat Edaran Direktur Jenderal Pajak No. SE51/PJ.43/1995, yaitu: (i) penghasilan yang bersumber dari pekerjaan, misalnya pengurus atau pimpinan rumah sakit/klinik/organisasi sosial kemanusiaan/universitas, dan pegawai tetap di rumah sakit/klinik/universitas (dosen)/organisasi sosial kemanusiaan/perusahaan; serta (ii) penghasilan yang bersumber dari pekerjaan bebas, misalnya praktik dokter sendiri (membuka klinik pribadi/praktik di rumah); praktik dokter di rumah sakit/klinik, baik sebagai dokter tetap/dokter tamu/dokter yang menyewa ruangan di rumah sakit sebagai tempat praktiknya. Dokter yang menjadi pegawai dapat memiliki status sebagai pegawai negeri atau pegawai swasta, di mana pegawai negeri terdiri dari Pegawai Negeri Sipil (PNS), anggota Kepolisian Negara Republik Indonesia (POLRI), dan anggota Tentara Nasional Indonesia (TNI). Apabila dokter sebagai Wajib Pajak orang pribadi melakukan pekerjaan bebas atau kegiatan usaha, maka wajib menyelenggarakan pembukuan jika peredaran brutonya dalam satu tahun mencapai Rp4.800.000.000,00. Sedangkan, dokter yang melakukan pekerjaan bebas atau kegiatan usaha dan peredaran brutonya dalam satu tahun kurang dari Rp4.800.000.000,00 diperbolehkan menghitung penghasilan neto dengan menggunakan Norma Penghitungan Penghasilan Neto (NPPN) dan wajib melakukan pencatatan kecuali dokter yang bersangkutan memilih 


\section{October, 2020}

menyelenggarakan pembukuan. Secara umum peraturan yang mengatur pembukuan dan pencatatan adalah Pasal 28 dalam UU No. 16 Tahun 2009 tentang Ketentuan Umum dan Tata Cara Perpajakan. Namun, untuk lebih lanjut ketentuan pencatatan bagi Wajib Pajak orang pribadi diatur dalam Peraturan Direktur Jenderal Pajak No. PER-4/PJ/2009 serta untuk NPPN diatur juga dalam Pasal 14 UU PPh dan Peraturan Direktur Jenderal Pajak No. PER-17/PJ./2015.

Dengan berbagai jenis penghasilan yang diperoleh dokter, maka besarnya penghasilan mungkin melebihi batas PTKP. Sehingga seorang dokter berpotensi menjadi wajib pajak. Kewajiban perpajakan dokter sebagai wajib pajak sama dengan wajib pajak pada umumnya, yaitu mendaftarkan diri untuk mendapatkan Nomor Pokok Wajib Pajak (NPWP) pada Kantor Pelayanan Pajak (KPP) yang wilayah kerjanya meliputi tempat tinggal; melunasi $\mathrm{PPh}$ dalam tahun berjalan dan akhir tahun pajak baik melalui pemotongan/pemungutan yang dilakukan oleh pihak lain maupun pembayaran oleh sendiri; serta mengisi dan menyampaikan Surat Pemberitahuan (SPT) PPh Masa dan Tahunan. Berbagai jenis penghasilan yang diperoleh dokter tersebut dapat dikenakan perlakuan PPh yang berbeda. Selain berbagai jenis penghasilan, dengan status pegawai negeri atau pegawai swasta yang dimiliki oleh dokter tersebut mungkin terdapat persamaan maupun perbedaan perlakuan $\mathrm{PPh}$ atas penghasilan yang diperolehnya. Perlakuan $\mathrm{PPh}$ atas penghasilan yang diperoleh dokter, secara umum diatur berdasarkan UU No. 36 Tahun 2008 tentang Perubahan Keempat atas UU No. 7 Tahun 1983 tentang PPh.

\section{METODE PENELITIAN}

Metode penelitian yang digunakan dalam penelitian ini adalah metode penelitian deskriptif. Metode tersebut dipilih sebab sesuai dengan tujuan penelitian, yaitu menjelaskan sesuatu yang terjadi. Data yang digunakan bersifat kualitatif karena berkaitan dengan Undang-Undang dan peraturan perpajakan yang berlaku, serta data diolah terlebih dahulu melalui proses perhitungan. Objek penelitian dalam penelitian ini adalah Pajak Penghasilan $(\mathrm{PPh})$ dokter. Penelitian yang dilakukan adalah studi kasus pada dokter dengan status yang berbeda, untuk dianalisis perlakuan PPh atas penghasilan yang diperoleh setiap dokter tersebut. Studi kasus dalam penelitian ini berfokus pada dr. N selaku Wajib Pajak orang pribadi dalam negeri yang berprofesi dokter dengan status sebagai pegawai negeri dan dr. $\mathrm{S}$ selaku Wajib Pajak orang pribadi dalam negeri yang berprofesi dokter dengan status sebagai pegawai swasta.

Sumber data dalam penelitian ini adalah data primer dan data sekunder. Data primer diperoleh dari data bukti pembayaran pajak, yaitu bukti pemotongan $\mathrm{PPh}$ Pasal 21 bagi PNS atau anggota TNI atau anggota POLRI atau pejabat negara atau 
pensiunannya (Formulir 1721-A2) milik dr. N, bukti pemotongan PPh Pasal 21 bagi pegawai tetap atau penerima pensiun atau tunjangan hari tua/jaminan hari tua berkala (Formulir 1721-A1) milik dr. S, bukti pemotongan PPh Pasal 21 tidak final atau Pasal 26 (Formulir 1721-VI) milik dr. N, bukti pemotongan PPh Pasal 21 final (Formulir 1721-VII) milik dr. N, Surat Setoran Pajak (SSP) milik dr. N, serta data pelaporan pajak, yaitu Surat Pemberitahuan (SPT) Tahunan PPh Wajib Pajak orang pribadi milik dr. $\mathrm{N}$ dan dr. S. Data sekunder diperoleh dari artikel ilmiah, buku, laporan keuangan pemerintah pusat tahun 2017 audited; peraturan mengenai PNS, anggota POLRI, dan anggota TNI; peraturan mengenai profesi dokter; peraturan-peraturan pajak; serta sumber resmi lainnya. Teknik pengumpulan data primer dan data sekunder tersebut, yaitu melalui studi lapangan juga studi literatur. Studi lapangan dilakukan dengan metode wawancara kepada dr. $\mathrm{N}$ dan dr. $\mathrm{S}$ serta metode dokumentasi dengan mengumpulkan data bukti pembayaran pajak dan data pelaporan pajak milik dr. N dan dr. S. Studi literatur bersumber dari textbooks dan reports terkait masalah yang diteliti, lalu akan digunakan sebagai landasan teori dan pedoman dalam pembahasan masalah.

Setelah terkumpul semua data yang diperlukan untuk penelitian, maka selanjutnya data diolah dengan tujuan untuk memperoleh informasi yang dapat mendukung proses penelitian lebih lanjut. Pengolahan data dilakukan karena data yang dikumpulkan merupakan data mentah yang cenderung sulit untuk dimengerti. Setelah data diolah, peneliti melakukan analisis data dengan cara melakukan perbandingan antara data yang diperoleh secara langsung dari studi kasus penelitian dengan teori-teori dan peraturan-peraturan yang relevan untuk mendapatkan hasil yang diharapkan, mencapai tujuan dilakukannya penelitian, serta menjawab rumusan masalah yang telah ditentukan. Berikut langkah-langkah analisis data dalam penelitian ini.

a. Melakukan analisis mengenai teori dan peraturan $\mathrm{PPh}$ terkait atas berbagai jenis penghasilan yang diperoleh dokter dengan setiap statusnya.

b. Melakukan pengolahan data dokumentasi sehingga didapatkan informasi tentang perlakuan $\mathrm{PPh}$ bagi dokter dengan status pegawai negeri dan pegawai swasta yang sesuai dengan peraturan pajak yang berlaku.

c. Mencari persamaan dan perbedaan perlakuan $\mathrm{PPh}$ dokter dengan status pegawai negeri dan dokter dengan status pegawai swasta.

\section{HASIL DAN PEMBAHASAN}

\section{Perlakuan Pajak Penghasilan Bagi Dokter}

Sama halnya dengan penghasilan yang diperoleh Wajib Pajak orang pribadi dalam negeri pada umumnya, penghasilan yang diperoleh dokter dengan status sebagai 
pegawai negeri atau pegawai swasta juga diatur berdasarkan UU PPh. Oleh karena itu, dokter dengan status sebagai pegawai negeri dan pegawai swasta dapat memperoleh penghasilan-penghasilan yang dikategorikan sebagai penghasilan yang termasuk dalam objek $\mathrm{PPh}$ atau penghasilan yang dikecualikan dari objek $\mathrm{PPh}$. Saat dokter dengan status sebagai pegawai negeri atau pegawai swasta menerima penghasilan yang termasuk dalam objek $\mathrm{PPh}$, maka akan dikenakan $\mathrm{PPh}$. Sifat pengenaan $\mathrm{PPh}$ atas penghasilan yang termasuk dalam objek $\mathrm{PPh}$ tersebut dapat dibedakan menjadi dua macam, yaitu penghasilan yang dikenakan pajak bersifat final dan penghasilan yang dikenakan pajak bersifat tidak final. Jika, dokter dengan status sebagai pegawai negeri atau pegawai swasta menerima penghasilan yang dikenakan PPh bersifat final, maka penghasilan tersebut tidak perlu digabung dengan penghasilan lainnya dalam perhitungan $\mathrm{PPh}$ yang terutang pada akhir tahun pajak, tetapi cukup dilaporkan saja jumlah penghasilannya dalam SPT Tahunan PPh Wajib Pajak orang pribadi. Demikian pula, PPh yang bersifat final yang telah disetor sendiri oleh penerima penghasilan ataupun dipotong/dipungut oleh pemotong/pemungut $\mathrm{PPh}$, tidak dapat dikreditkan dengan $\mathrm{PPh}$ yang terutang pada akhir tahun pajak. Penyetoran sendiri atau pemotongan/pemungutan $\mathrm{PPh}$ yang bersifat final tersebut merupakan cara pelunasan PPh dalam tahun berjalan. Sedangkan, jika dokter dengan status sebagai pegawai negeri atau pegawai swasta menerima penghasilan yang dikenakan $\mathrm{PPh}$ bersifat tidak final, maka penghasilan tersebut perlu digabung dengan penghasilan lainnya dalam perhitungan $\mathrm{PPh}$ yang terutang pada akhir tahun pajak saat pengisian SPT Tahunan PPh Wajib Pajak orang pribadi. Demikian pula, PPh yang bersifat tidak final yang telah disetor sendiri oleh penerima penghasilan ataupun dipotong/dipungut oleh pemotong/pemungut $\mathrm{PPh}$ tersebut, dapat dikreditkan dengan PPh yang terutang pada akhir tahun pajak. Penyetoran sendiri atau pemotongan/pemungutan $\mathrm{PPh}$ yang bersifat tidak final merupakan cara pelunasan $\mathrm{PPh}$ dalam tahun berjalan. Apabila dokter dengan status sebagai pegawai negeri atau pegawai swasta menerima penghasilan yang dikecualikan dari objek $\mathrm{PPh}$, maka tidak dikenakan PPh. Meskipun demikian, dokter dengan status sebagai pegawai negeri atau pegawai swasta yang memperoleh penghasilan yang dikecualikan dari objek PPh tetap harus melaporkan jumlah penghasilan tersebut dalam SPT Tahunan PPh Wajib Pajak orang pribadi, tetapi tidak diperhitungkan untuk $\mathrm{PPh}$ yang terutang pada akhir tahun pajak dalam SPT Tahunan PPh tersebut.

Dengan tetap memperhatikan penghasilan utama dokter dengan status sebagai pegawai negeri atau pegawai swasta adalah penghasilan yang terkait dengan profesi dokter tersebut, berikut ini perlakuan $\mathrm{PPh}$ atas beberapa jenis penghasilan yang menurut peneliti mungkin diterima oleh dokter dengan status sebagai pegawai negeri atau pegawai swasta.

Bisnis Dan Iptek | Sekolah Tinggi Ilmu Ekonomi Pasundan Bandung 
Tabel 1. Perlakuan PPh atas Penghasilan yang Diperoleh Dokter dengan Status sebagai Pegawai Negeri atau Pegawai Swasta

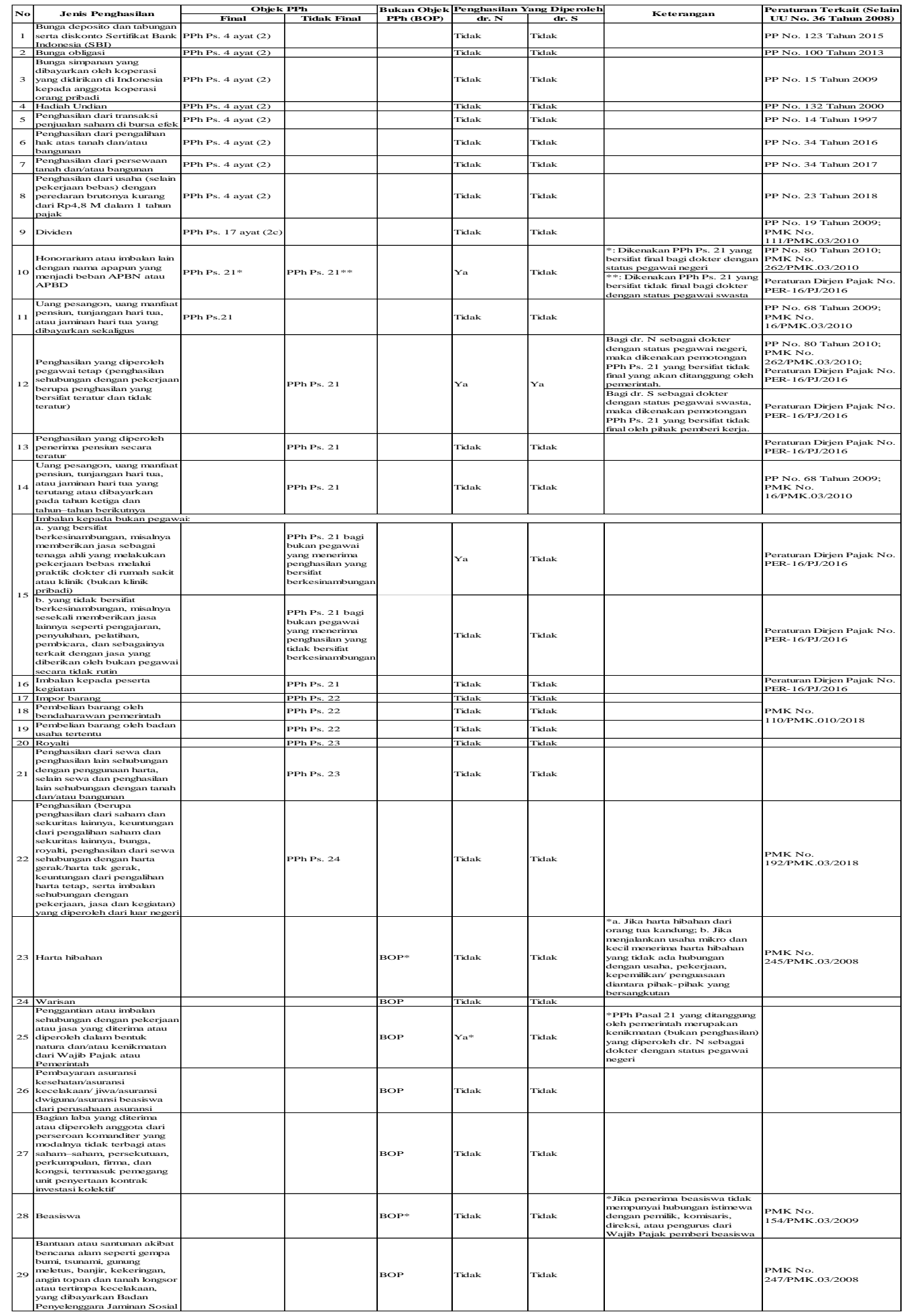

Sumber: Data Olahan Penelitian (2019) 


\section{October, 2020}

\section{Pengenaan PPh Bagi dr. N dan dr. S Pada Tahun Pajak 2018}

Dari tabel 1. menunjukkan bahwa, pada tahun pajak 2018 dr. N dan dr. S hanya menerima penghasilan terkait dengan pekerjaan dan jasa tenaga ahli yang melakukan pekerjaan bebas melalui praktik dokter. Berikut ini perhitungan PPh yang dikenakan kepada dr. $\mathrm{N}$ dan dr. S.

1. Perhitungan PPh bagi dr. N selaku dokter dengan status pegawai negeri

dr. N merupakan dokter spesialis obstetri \& ginekologi yang melakukan praktik dokter di Rumah Sakit X dan Klinik Y. dr. N bertempat tinggal di Bandung dan telah terdaftar sebagai Wajib Pajak. dr. $\mathrm{N}$ memiliki istri yang merupakan ibu rumah tangga dan memiliki 2 orang anak kandung yang merupakan pelajar. Maka, penghasilan tidak kena pajak (PTKP) untuk dr. N adalah K/2. Sebagai seorang pegawai negeri (PNS), dr. $\mathrm{N}$ mendapatkan penghasilan sehubungan dengan pekerjaan berupa penghasilan yang bersifat teratur dan tidak teratur serta honorarium atau imbalan lain (remunerasi) yang menjadi beban APBN atau APBD. Selain itu, dr. N termasuk bukan pegawai yang menerima penghasilan sehubungan dengan pemberian jasa sebagai tenaga ahli yang melakukan pekerjaan bebas melalui praktik dokter di klinik Y dengan status hubungan kerja sebagai dokter tetap, yaitu berupa imbalan kepada tenaga ahli yang besarnya berbedabeda setiap bulan.

Dari informasi tersebut, maka dr. $\mathrm{N}$ memiliki kewajiban $\mathrm{PPh}$ atas penghasilan yang diperolehnya. Sebelum melunasi dan melaporkan PPh yang terutang pada akhir tahun pajak, dr. $\mathrm{N}$ melakukan pelunasan $\mathrm{PPh}$ dalam tahun berjalan, yaitu sebagai berikut.

a. $\quad$ PPh yang dipotong oleh pemotong PPh (pemberi kerja dr. N)

i. $\quad$ PPh Pasal 21 bagi pegawai tetap yang bersifat tidak final dan ditanggung oleh pemerintah atas penghasilan yang bersifat teratur dan tidak teratur (penghasilan tetap dan teratur setiap bulan)

Pemotongan PPh Pasal 21 tersebut dihitung, disetorkan, dan dilaporkan oleh Bendahara Pengeluaran Rumah Sakit X. Selain itu, Bendahara Pengeluaran Rumah Sakit X harus memberikan bukti pemotongan PPh Pasal 21 bagi PNS atau anggota TNI atau anggota POLRI atau pejabat negara atau pensiunannya (Formulir 1721-A2) kepada dr. N paling lambat tanggal 31 Januari 2019. Sebab, bukti pemotongan PPh Pasal 21 tersebut harus dilampirkan saat dr. N melaporkan SPT Tahunan PPh Wajib Pajak orang pribadi (Formulir 1770) untuk tahun pajak 2018. Di dalam bukti pemotongan PPh Pasal 21 tersebut juga terdapat rincian perhitungannya. 
Tabel 2. Perhitungan PPh Pasal 21 atas penghasilan tetap dan teratur setiap bulan yang dikenakan terhadap $\mathrm{dr}$. $\mathrm{N}$

\begin{tabular}{|c|c|}
\hline Gaji pokok & Rp 40.756 .700 \\
\hline Tunjangan istri & $\mathrm{Rp} \quad 4.075 .670$ \\
\hline Tunjangan anak & $\mathrm{Rp} \quad 1.630 .268$ \\
\hline Tunjangan perbaikan penghasilan & Rp 33.004.813 \\
\hline Tunjangan struktural/fungsional & $\mathrm{Rp} \quad 7.020 .000$ \\
\hline Tunjangan beras & Rp $\quad 3.476 .160$ \\
\hline Tunjangan khusus & - \\
\hline Tunjangan lain-lain & - \\
\hline $\begin{array}{l}\text { Penghasilan tetap dan teratur lainnya yang pembayarannya terpisah } \\
\text { dari pembayaran gaji }\end{array}$ & \\
\hline Jumlah penghasilan bruto setahun & Rp 89.963.611 \\
\hline \multicolumn{2}{|l|}{ Pengurang: } \\
\hline Biaya jabatan (5\% x penghasilan bruto setahun, maks. Rp6.000.000) & $\operatorname{Rp}(4.498 .181)$ \\
\hline Iuran pensiun atau Iuran THT/JHT yang dibayar pegawai & $\underline{\operatorname{Rp}(2.206 .975)}$ \\
\hline Jumlah penghasilan neto setahun & Rp 83.258.455 \\
\hline Penghasilan Tidak Kena Pajak (K/2) per tahun & $\underline{\operatorname{Rp}(67.500 .000)}$ \\
\hline Penghasilan Kena Pajak (PKP) setahun & $\mathrm{Rp} 15.758 .455$ \\
\hline Penghasilan Kena Pajak (PKP) setahun dibulatkan & Rp 15.758 .000 \\
\hline $\begin{array}{l}\text { PPh Pasal } 21 \text { terutang setahun (Tarif PPh Ps. } 17 \text { ayat (1) huruf } \\
\text { a x PKP) }\end{array}$ & Rp $\quad 787.900$ \\
\hline
\end{tabular}

Sumber: Data Olahan Penelitian (2019)

ii. $\quad$ PPh Pasal 21 bagi pegawai tetap yang bersifat final atas honorarium atau imbalan lain (remunerasi) yang menjadi beban APBN atau APBD

Pemotongan PPh Pasal 21 tersebut dihitung, disetorkan, dan dilaporkan oleh Bendahara Pengeluaran Rumah Sakit X. Selain itu, Bendahara Pengeluaran Rumah Sakit $\mathrm{X}$ harus memberikan bukti pemotongan PPh Pasal 21 Final (Formulir 1721-VII) kepada dr. N paling lambat pada akhir bulan setiap pembayaran honorarium atau imbalan lain (remunerasi) yang dibebankan kepada APBN atau APBD. Bukti pemotongan PPh Pasal 21 tersebut harus dilampirkan saat dr. N melaporkan SPT Tahunan PPh Wajib Pajak orang pribadi (Formulir 1770) untuk tahun pajak 2018. Di dalam bukti pemotongan PPh Pasal 21 tersebut juga terdapat rincian perhitungannya, yaitu dengan cara mengalikan penghasilan bruto honorarium dengan tarif PPh Pasal 21 final sebesar 5\%. Tarif PPh Pasal 21 yang bersifat final ini sesuai dengan golongan dari PNS dr. N, yaitu golongan III. 
Tabel 3. Perhitungan PPh Pasal 21 atas honorarium atau imbalan lain (remunerasi) yang menjadi beban APBN/APBD yang dikenakan terhadap dr. $\mathbf{N}$

\begin{tabular}{|c|c|c|c|c|c|c|}
\hline \multirow{2}{*}{ No } & \multirow{2}{*}{ Bulan } & \multicolumn{2}{|c|}{ Remunerasi (Rp) } & \multirow{2}{*}{\begin{tabular}{|c|} 
Jumlah Kotor \\
Remunerasi \\
$(\mathbf{R p})$
\end{tabular}} & \multirow{2}{*}{\begin{tabular}{|c|} 
Tarif PPh \\
Pasal 21 \\
Final \\
\end{tabular}} & \multirow{2}{*}{$\begin{array}{c}\text { PPh Pasal } 21 \\
\text { Final (Rp) }\end{array}$} \\
\hline & & P1 & $\mathbf{P 2}$ & & & \\
\hline 1. & Januari & 5.726 .720 & 9.019 .580 & \begin{tabular}{|l|}
14.746 .300 \\
\end{tabular} & \begin{tabular}{|l|}
$5 \%$ \\
\end{tabular} & 737.315 \\
\hline 2 & Februari & 5.973 .720 & 9.408 .610 & 15.382 .330 & $5 \%$ & 769.117 \\
\hline 3 & Maret & 5.973 .720 & 15.681 .000 & 21.654 .720 & $5 \%$ & 1.082 .736 \\
\hline 4 & April & 5.989 .780 & 15.723 .200 & 21.712 .980 & $5 \%$ & 1.085 .649 \\
\hline 5 & Mei & 5.989 .780 & 26.205 .300 & 32.195 .080 & $5 \%$ & 1.609 .754 \\
\hline 6 & Juni & 5.989 .780 & 20.964 .200 & 26.953 .980 & $5 \%$ & 1.347 .699 \\
\hline 7. & Juli & 5.989 .780 & 20.964 .200 & 26.953 .980 & $5 \%$ & 1.347 .699 \\
\hline 8 & Agustus & 5.989 .780 & 20.964 .200 & 26.953 .980 & $5 \%$ & 1.347 .699 \\
\hline 9 & September & 5.989 .780 & 15.723 .200 & 21.712 .980 & $5 \%$ & 1.085 .649 \\
\hline 10 & Oktober & 5.989 .780 & 15.723 .200 & 21.712 .980 & $5 \%$ & 1.085 .649 \\
\hline 11 & November & 5.989 .780 & 20.964 .200 & 26.953 .980 & $5 \%$ & 1.347 .699 \\
\hline 12 & Desember & 5.989 .780 & 26.205 .300 & 32.195 .080 & $5 \%$ & 1.609 .754 \\
\hline 13 & Remunerasi Ke-13 & 5.989 .780 & 26.205 .300 & 32.195 .080 & $5 \%$ & 1.609 .754 \\
\hline 14 & Penyesuaian PIR & 2.788 .640 & 9.760 .250 & 12.548 .890 & $5 \%$ & 627.445 \\
\hline \multicolumn{4}{|c|}{$\begin{array}{l}\text { Jumlah Total } \\
\end{array}$} & 333.872 .340 & & 16.693 .617 \\
\hline
\end{tabular}

Sumber: Data Olahan Penelitian (2019)

iii. PPh Pasal 21 bagi bukan pegawai yang bersifat tidak final atas imbalan yang bersifat berkesinambungan dan mempunyai penghasilan lain

Pemotongan PPh Pasal 21 tersebut dihitung, disetorkan, dan dilaporkan oleh Klinik Y. Selain itu, Klinik Y harus memberikan bukti pemotongan PPh Pasal 21 tidak final atau Pasal 26 (Formulir 1721-VI) kepada dr. N paling lambat 1 bulan setelah tahun kalender berakhir berarti tanggal 31 Januari 2019. Bukti pemotongan PPh Pasal 21 tersebut harus dilampirkan saat dr. N melaporkan SPT Tahunan PPh Wajib Pajak orang pribadi (Formulir 1770) untuk tahun pajak 2018. Di dalam bukti pemotongan $\mathrm{PPh}$ Pasal 21 tersebut, terdapat rincian perhitungannya, yaitu dengan cara menghitung terlebih dahulu dasar pengenaan $\mathrm{PPh}$ bagi bukan pegawai yang menerima penghasilan yang bersifat berkesinambungan, yaitu $50 \%$ dari jumlah penghasilan bruto yang dibayarkan kepada dr. $\mathrm{N}$ sehubungan dengan praktik dokter di Klinik Y. Hasil dasar pengenaan $\mathrm{PPh}$ tersebut dikumulatifkan jumlahnya dalam setahun, kemudian dikalikan dengan Tarif PPh Pasal 17 ayat (1) huruf a UU PPh. Dasar pengenaan $\mathrm{PPh}$ tersebut dikumulatifkan karena penghasilan yang dibayarkan kepada dr. $\mathrm{N}$ bersifat berkesinambungan atau lebih dari satu kali dalam satu tahun kalender 2018 dan untuk menentukan pengenaan lapisan Tarif PPh Pasal 17 ayat (1) huruf a UU PPh. Dalam perhitungan PPh Pasal 21 ini tidak dapat memperoleh 
pengurangan PTKP karena dr. $\mathrm{N}$ memperoleh penghasilan lainnya selain dari Klinik Y yang telah dikurangi PTKP, yaitu penghasilan tetap dan teratur setiap bulan yang dipotong PPh Pasal 21 bagi pegawai tetap.

Tabel 4. Perhitungan PPh Pasal 21 atas imbalan yang bersifat berkesinambungan dan mempunyai penghasilan lain yang dikenakan terhadap dr. $\mathbf{N}$

\begin{tabular}{|l|l|r|r|r|r|r|r|}
\hline No & Bulan & $\begin{array}{c}\text { Jumlah } \\
\text { Penghasilan } \\
\text { Bruto (Rp) }\end{array}$ & $\begin{array}{c}\text { Dasar } \\
\text { Pengenaan } \\
\text { Pajak (Rp) }\end{array}$ & $\begin{array}{c}\text { Dasar } \\
\text { Pengenaan } \\
\text { Pajak } \\
\text { Kumulatif } \\
\mathbf{( R p )}\end{array}$ & $\begin{array}{c}\text { Dasar } \\
\text { Pengenaan } \\
\text { Pajak } \\
\text { Berdasarkan } \\
\text { Kumulatif (Rp) }\end{array}$ & $\begin{array}{c}\text { Tarif } \\
\text { PPh } \\
\text { Pasal } \\
\mathbf{2 1}\end{array}$ & $\begin{array}{c}\text { PPh Pasal } \\
\text { 21 Yang } \\
\text { Dipotong } \\
\text { (Rp) }\end{array}$ \\
\hline 1 & Januari & 7.217 .895 & 3.608 .948 & 3.608 .948 & 3.608 .948 & $5 \%$ & 180.447 \\
\hline 2 & Februari & 15.952 .358 & 7.976 .179 & 11.585 .127 & 7.976 .179 & $5 \%$ & 398.809 \\
\hline 3 & Maret & 12.097 .869 & 6.048 .935 & 17.634 .061 & 6.048 .935 & $5 \%$ & 302.447 \\
\hline 4 & April & 20.752 .176 & 10.376 .088 & 28.010 .149 & 10.376 .088 & $5 \%$ & 518.804 \\
\hline 5 & Mei & 30.891 .097 & 15.445 .549 & 43.455 .698 & 15.445 .549 & $5 \%$ & 772.277 \\
\hline 6 & Juni & 33.182 .705 & 16.591 .353 & 50.000 .000 & 6.544 .303 & $5 \%$ & 327.215 \\
\cline { 5 - 9 } & & & 60.047 .050 & 10.047 .050 & $15 \%$ & 1.507 .058 \\
\hline 7 & Juli & 44.384 .308 & 22.192 .154 & 82.239 .204 & 22.192 .154 & $15 \%$ & 3.328 .823 \\
\hline 8 & Agustus & 26.316 .256 & 13.158 .128 & 95.397 .332 & 13.158 .128 & $15 \%$ & 1.973 .719 \\
\hline 9 & September & 44.424 .178 & 22.212 .089 & 117.609 .421 & 22.212 .089 & $15 \%$ & 3.331 .813 \\
\hline 10 & Oktober & 30.528 .053 & 15.264 .027 & 132.873 .448 & 15.264 .027 & $15 \%$ & 2.289 .604 \\
\hline 11 & November & 32.448 .348 & 16.224 .174 & 149.097 .622 & 16.224 .174 & $15 \%$ & 2.433 .626 \\
\hline 12 & Desember & 30.689 .843 & 15.344 .922 & 164.442 .543 & 15.344 .922 & $15 \%$ & 2.301 .738 \\
\hline Jumlah Total & 328.885 .086 & 164.442 .543 & & 164.442 .543 & & 19.666 .381 \\
\hline
\end{tabular}

Sumber: Data Olahan Penelitian (2019)

\section{b. $\quad$ PPh yang disetor sendiri oleh dr. $\mathrm{N}$}

Selain dipotong oleh pemotong pajak, pelunasan $\mathrm{PPh}$ dalam tahun berjalan juga dapat disetor sendiri oleh dr. N melalui pembayaran angsuran PPh Pasal 25. Besarnya angsuran PPh Pasal 25 yang disetorkan setiap bulan oleh dr. $\mathrm{N}$ adalah Rp135.000,00 selama 12 bulan, maka jumlah angsuran PPh Pasal 25 yang disetorkan oleh dr. N pada tahun pajak 2018 sebesar Rp1.620.000,00.

Setelah pelunasan $\mathrm{PPh}$ dalam tahun berjalan, selanjutnya menghitung $\mathrm{PPh}$ yang terutang pada akhir tahun pajak 2018 bagi dr. N dengan mengacu pada SPT Tahunan PPh Wajib Pajak orang pribadi (Formulir 1770), karena dr. N mempunyai penghasilan sehubungan dengan pekerjaan dari 1 pemberi kerja serta penghasilan dari pekerjaan bebas melalui praktik dokter. Ada beberapa tahap dalam menghitung PPh yang terutang pada akhir tahun pajak 2018 bagi dr. N, yaitu sebagai berikut. 
Tabel 5. Perhitungan PPh yang terutang pada akhir tahun pajak 2018 bagi dr. $\mathbf{N}$

\begin{tabular}{|c|c|c|}
\hline Penghasilan neto dalam negeri dari pekerjaan bebas & Rp164.442.543 & [50\%×Rp328.885.086] \\
\hline Penghasilan neto dalam negeri sehubungan dengan pekerjaan & Rp 83.258.455 & \\
\hline Penghasilan neto dalam negeri lainnya & - & \\
\hline Penghasilan neto luar negeri & - & \\
\hline Jumlah Penghasilan Neto & Rp247.700.998 & \\
\hline Zakat/sumbangan keagamaan yang bersifat wajib & - & \\
\hline Kompensasi Kerugian & - & \\
\hline Jumlah Penghasilan Neto Setelah Pengurangan Zakat/Sumbangan & & \\
\hline Keagamaan yang Bersifat Wajib dan Kompensasi Kerugian & Rp247.700.998 & \\
\hline Penghasilan Tidak Kena Pajak (K/2) & $\underline{\operatorname{Rp}(67.500 .000)}$ & \\
\hline Penghasilan Kena Pajak & $\underline{\mathrm{Rp} 180.200 .998}$ & \\
\hline Penghasilan Kena Pajak Pembulatan & Rp180.200.000 & \\
\hline $\begin{array}{l}\text { Pajak Penghasilan Terutang (Tarif PPh Ps. } 17 \text { ayat (1) huruf a x } \\
\text { PKP) }\end{array}$ & Rp 22.030 .000 & $\begin{array}{l}{[(5 \% \times \mathrm{Rp} 50.000 .000)+} \\
(15 \% \times \mathrm{Rp} 130.200 .000)]\end{array}$ \\
\hline Pengembalian/pengurangan $\mathrm{PPh}$ Pasal 24 yang telah dikreditkan & - & \\
\hline Jumlah Pajak Penghasilan Terutang & Rp 22.030 .000 & \\
\hline $\begin{array}{l}\mathrm{PPh} \text { yang dipotong/dipungut pihak lain, } \mathrm{PPh} \text { ditanggung Pemerintah, dan } \\
\mathrm{PPh} \text { yang dibayar/dipotong di Luar Negeri }\end{array}$ & $\underline{\operatorname{Rp}(20.454 .281)}$ & [Rp787.900+Rp19.666.381] \\
\hline PPh yang harus dibayar sendiri/(PPh yang lebih dipotong/dipungut) & Rp 1.575 .719 & \\
\hline PPh yang dibayar sendiri (PPh Pasal 25) & $\underline{\mathrm{Rp}(1.620 .000)}$ & \\
\hline \multicolumn{3}{|l|}{ PPh yang kurang dibayar (PPh Pasal 29)/ } \\
\hline PPh yang lebih dibayar (PPh Pasal 28 A)/ & $(44.281)$ & \\
\hline PPh Nihil & - & \\
\hline Angsuran PPh Pasal 25 Tahun Pajak Berikutnya & 131.310 & {$[\mathrm{Rp} 1.575 .719 / 12]$} \\
\hline
\end{tabular}

Sumber: Data Olahan Penelitian (2019)

Tahap pertama adalah menghitung jumlah penghasilan neto dari seluruh penghasilan yang diterima oleh dr. N. Untuk perhitungan jumlah penghasilan neto dalam negeri dari pekerjaan bebas yang diperoleh dr. N pada tahun pajak 2018, dr. $\mathrm{N}$ diperbolehkan menggunakan Norma Penghitungan Penghasilan Neto (NPPN) dengan wajib melakukan pencatatan, karena jumlah penghasilan bruto dari pekerjaan bebas yang diperoleh dr. N pada tahun 2018 kurang dari Rp4,8 M yakni sebesar Rp328.885.086,00. Jumlah tersebut berasal dari penjumlahan penghasilan bruto praktik dokter di Klinik Y selama tahun 2018. Dalam hal penggunaan NPPN di tahun pajak 2018, dr. N harus memberitahukan kepada Direktur Jenderal Pajak melalui penyampaian surat pemberitahuan penggunaan norma dalam jangka waktu 3 bulan pertama pada tahun pajak 2018, yaitu bulan Januari hingga Maret 2018. Untuk mendapatkan jumlah penghasilan neto dalam negeri dari pekerjaan bebas dihitung dengan cara mengalikan jumlah penghasilan bruto dari pekerjaan bebas yang diperoleh dr. N pada tahun 2018 sebesar Rp328.885.086,00 dengan persentase NPPN yang berlaku pada tahun pajak 2018 untuk jenis usaha dokter di wilayah Bandung sebesar 50\%, maka jumlahnya Rp164.442.543,00. Sedangkan, jumlah penghasilan neto dalam negeri sehubungan dengan pekerjaan yang 
diperoleh dr. $\mathrm{N}$ pada tahun pajak 2018 sama dengan jumlah penghasilan neto setahun yang dikenakan PPh Pasal 21 bagi pegawai yang bersifat tidak final dan ditanggung pemerintah atas penghasilan yang sifatnya tetap dan teratur setiap bulan, yaitu sebesar Rp83.258.455,00. Setelah mendapatkan jumlah penghasilan neto dalam negeri sehubungan dengan pekerjaan dan jumlah penghasilan neto dalam negeri dari pekerjaan bebas, kemudian jumlahkan agar mendapatkan jumlah penghasilan neto setahun, maka diperoleh jumlahnya sebesar Rp247.700.998,00.

Pada tahun 2018, dr. $\mathrm{N}$ tidak membayarkan zakat/sumbangan keagamaan yang bersifat wajib kepada badan amil zakat atau lembaga amil zakat yang dibentuk atau disahkan oleh Pemerintah sesuai dengan bukti setoran yang sah. Untuk kompensasi kerugian hanya akan terjadi bagi Wajib Pajak yang menyelenggarakan pembukuan karena pada pencatatan tidak ada kerugian fiskal. Bagi dr. N tidak ada kompensasi kerugian sebab menyelenggarakan pencatatan. Sehingga, jumlah penghasilan neto setahun setelah pengurangan zakat/sumbangan keagamaan yang bersifat wajib dan kompensasi kerugian sama dengan jumlah penghasilan neto setahun, yaitu Rp247.700.998,00.

Tahap selanjutnya adalah menghitung Penghasilan Kena Pajak (PKP) sebagai dasar perhitungan PPh yang terutang pada akhir tahun pajak 2018 bagi dr. N, yaitu dengan cara mengurangi jumlah penghasilan neto setahun setelah pengurangan zakat/sumbangan keagamaan yang bersifat wajib dan kompensasi kerugian dengan besarnya PTKP. PTKP bagi dr. N adalah K/2. Besarnya jumlah PTKP per tahun untuk status K/2 pada tahun pajak 2018 adalah Rp67.500.000,00. Maka, besarnya PKP adalah Rp180.200.998,00.

Tahap terakhir yang harus dilakukan untuk memperoleh besarnya PPh yang terutang pada akhir tahun pajak 2018 bagi dr. N, yaitu mengalikan PKP dengan tarif PPh Pasal 17 ayat (1) huruf a UU PPh. Dalam penerapan tarif PPh tersebut, jumlah PKP dibulatkan ke bawah dalam ribuan rupiah penuh menjadi Rp180.200.000,00. Maka perhitungan PPh yang terutang pada akhir tahun pajak 2018 bagi dr. $\mathrm{N}$ :

$$
\begin{array}{ll}
\mathrm{Rp} 50.000 .000,00 \times 5 \% & =\mathrm{Rp} 2.500 .000,00 \\
\mathrm{Rp} 130.200 .000,00 \times 15 \% & =\mathrm{Rp} 19.530 .000,00+ \\
\mathrm{PPh} \text { yang terutang } & =\mathrm{Rp} 22.030 .000,00
\end{array}
$$

Di 2018, dr. N tidak menerima pengembalian atau pengurangan PPh Pasal 24 yang telah dikreditkan, maka jumlah PPh yang terutang tetap sebesar Rp22.030.000,00.

Untuk pelunasan $\mathrm{PPh}$ pada akhir tahun pajak, tidak hanya sampai mendapatkan jumlah $\mathrm{PPh}$ yang terutang saja, namun dr. $\mathrm{N}$ juga harus mengetahui $\mathrm{PPh}$ yang terutang pada akhir tahun pajak ini lebih kecil atau lebih besar atau sama dengan 
kredit pajak, yaitu dengan cara mengurangi jumlah PPh yang terutang pada akhir tahun pajak dengan kredit pajak dr. N. Kredit pajak bagi dr. N adalah $\mathrm{PPh}$ yang dipotong/dipungut pihak lain, $\mathrm{PPh}$ ditanggung Pemerintah, dan $\mathrm{PPh}$ yang $\begin{array}{lllll}\text { dibayar/dipotong } & \text { di } & \text { LN } & \text { sebesar } & \text { Rp20.454.281,00 }\end{array}$ (Rp787.900,00+Rp19.666.381,00) serta PPh yang dibayar sendiri sebesar Rp1.620.000,00. Maka, pada akhir tahun pajak 2018, dr. N mengalami PPh Lebih Bayar (PPh Pasal 28A) sebesar Rp44.281,00. PPh lebih bayar ini dapat direstitusikan atau dikembalikan kepada dr. N. Untuk perhitungan angsuran $\mathrm{PPh}$ Pasal 25 tahun pajak 2019 didasarkan pada besarnya PPh yang harus dibayar sendiri/(PPh yang lebih dipotong/dipungut), yaitu Rp1.575.719,00 dibagi 12, maka besarnya Rp131.310,00.

2. Perhitungan PPh bagi dr. S selaku dokter dengan status pegawai swasta

dr. S merupakan dokter umum yang menjadi dokter perusahaan di PT Z, pengurus PMI KB, juga membuka praktik dokter di rumahnya. dr. S memiliki istri yang merupakan ibu rumah tangga serta memiliki 3 orang anak kandung yang merupakan mahasiswa dan belum memperoleh penghasilan. Sehingga, PTKP untuk dr. S adalah K/3. dr. S bertempat tinggal di Bandung dan telah terdaftar sebagai Wajib Pajak. Sebagai seorang pegawai swasta, dr. S mendapatkan gaji dan tunjangan lain-lain yang sifatnya tetap dan teratur setiap bulan dari PT Z, juga dari PMI KB. Selain itu, dr. S memperoleh penghasilan dari praktik dokter di rumahnya berupa penghasilan atas jasa medis dari pasien yang besarnya berbedabeda setiap bulan.

Dari informasi tersebut, maka dr. S memiliki kewajiban $\mathrm{PPh}$ atas penghasilan yang diperolehnya. Sebelum melunasi dan melaporkan PPh yang terutang pada akhir tahun pajak, dr.S melakukan pelunasan $\mathrm{PPh}$ dalam tahun berjalan, yaitu sebagai berikut.

a. $\quad$ PPh yang dipotong oleh pemotong $\mathrm{PPh}$ (pemberi kerja dr. S)

dr. S dikenakan pemotongan PPh Pasal 21 bagi pegawai tetap yang bersifat tidak final dan dipotong oleh PT Z dan PMI KB atas penghasilan yang bersifat teratur dan tidak teratur. Pemotongan PPh Pasal 21 tersebut dihitung, disetorkan, dan dilaporkan oleh PT Z juga PMI KB. Selain itu, baik PT Z maupun PMI KB harus memberikan bukti pemotongan PPh Pasal 21 bagi pegawai tetap atau penerima pensiun atau tunjangan hari tua/jaminan hari tua berkala (Formulir 1721-A1) kepada dr. S paling lambat tanggal 31 Januari 2019. Sebab, bukti pemotongan PPh Pasal 21 tersebut harus dilampirkan saat dr. S melaporkan SPT Tahunan PPh Wajib Pajak orang pribadi (Formulir 1770) untuk tahun pajak 2018. Di dalam bukti pemotongan $\mathrm{PPh}$ Pasal 21 tersebut juga terdapat rincian perhitungannya. 
Tabel 6. Perhitungan PPh Pasal 21 atas yang bersifat teratur dan tidak teratur yang dikenakan terhadap dr. S oleh PT Z

\begin{tabular}{|c|c|}
\hline Gaji & Rp108.850.000 \\
\hline Tunjangan $\mathrm{PPh}$ & - \\
\hline Tunjangan lainnya, uang lembur, dan sebagainya & - \\
\hline Honorarium dan imbalan lain sejenisnya & - \\
\hline Premi asuransi yang dibayar pemberi kerja & - \\
\hline $\begin{array}{l}\text { Penerimaan dalam bentuk natura dan kenikmatan lainnya yang } \\
\text { dikenakan pemotongan } \mathrm{PPh} \text { Pasal } 21\end{array}$ & \\
\hline Tantiem, bonus, gratifikasi, jasa produksi, dan THR & Rp $\quad 3.000 .000$ \\
\hline Jumlah penghasilan bruto setahun & Rp111.850.000 \\
\hline \multicolumn{2}{|l|}{ Pengurang: } \\
\hline Biaya jabatan (5\% x penghasilan bruto setahun, maks. Rp6.000.000) & $\operatorname{Rp}(5.592 .500)$ \\
\hline Iuran pensiun atau Iuran THT/JHT yang dibayar pegawai & - \\
\hline Jumlah penghasilan neto setahun & Rp106.257.500 \\
\hline Penghasilan Tidak Kena Pajak (K/3) per tahun & $\underline{\operatorname{Rp}(72.000 .000)}$ \\
\hline Penghasilan Kena Pajak (PKP) setahun & $\mathrm{Rp} 34.257 .500$ \\
\hline Penghasilan Kena Pajak (PKP) setahun dibulatkan & $\mathrm{Rp} 34.257 .000$ \\
\hline $\begin{array}{l}\text { PPh Pasal } 21 \text { terutang setahun (Tarif PPh Ps. } 17 \text { ayat (1) huruf } \\
\text { a x PKP) }\end{array}$ & $\begin{array}{ll}\mathrm{Rp} & 1.712 .850 \\
\end{array}$ \\
\hline
\end{tabular}

Sumber: Data Olahan Penelitian (2019)

Tabel 7. Perhitungan PPh Pasal 21 atas yang bersifat teratur dan tidak teratur yang dikenakan terhadap dr. S oleh PMI KB

\begin{tabular}{|l|r|}
\hline Jumlah penghasilan bruto setahun & $\mathrm{Rp} 36.000 .000$ \\
\hline \begin{tabular}{l} 
Pengurang: \\
\hline Biaya jabatan (5\% x penghasilan bruto setahun, maks. Rp6.000.000)
\end{tabular} & $\mathrm{Rp}(1.800 .000)$ \\
\hline Iuran pensiun atau Iuran THT/JHT yang dibayar pegawai & - \\
\hline Jumlah penghasilan neto setahun & $\mathrm{Rp} 34.200 .000$ \\
\hline Penghasilan Tidak Kena Pajak (K/3) per tahun & - \\
\hline Penghasilan Kena Pajak setahun & $\mathrm{Rp} 34.200 .000$ \\
\hline $\begin{array}{l}\text { Penghasilan Kena Pajak setahun dibulatkan } \\
\text { PPh Pasal 21 terutang setahun (Tarif PPh Ps. 17 ayat (1) huruf } \\
\text { a x PKP) }\end{array}$ & $\mathrm{Rp} 34.200 .000$ \\
\hline
\end{tabular}

Sumber: Data Olahan Penelitian (2019) 
Dalam perhitungan PPh Pasal 21 yang dipotong oleh PMI KB tidak diberikan pengurangan PTKP karena telah diberikan pengurangan PTKP untuk perhitungan PPh Pasal 21 yang dipotong oleh PT Z.

b. $\quad$ PPh yang disetor sendiri oleh dr. $\mathrm{S}$

dr. S tidak menyetor sendiri angsuran PPh Pasal 25 selama tahun pajak 2018. Padahal seharusnya dr. S menyetor angsuran PPh Pasal 25 setiap bulan, sebab dr. $\mathrm{S}$ memperoleh penghasilan dari pekerjaan bebas, yaitu penghasilan dari praktik dokter di rumahnya. Berikut ini pencatatan penghasilan bruto dari praktik dokter di rumah yang diperoleh dr. H setiap bulan.

Tabel 8. Pencatatan Penghasilan Bruto dari Praktik Dokter di Rumah dr. H

\begin{tabular}{|r|l|r|r|}
\hline No & Bulan & Penghasilan Bruto (Rp) & $\begin{array}{r}\text { Penghasilan Neto (Rp) } \\
{[\mathbf{5 0 \%} \text { x Penghasilan Bruto] }}\end{array}$ \\
\hline 1 & Januari & 2.450 .000 & 1.225 .000 \\
\hline 2 & Februari & 2.380 .000 & 1.190 .000 \\
\hline 3 & Maret & 2.680 .000 & 1.340 .000 \\
\hline 4 & April & 2.500 .000 & 1.250 .000 \\
\hline 5 & Mei & 2.840 .000 & 1.420 .000 \\
\hline 6 & Juni & 2.465 .000 & 1.232 .500 \\
\hline 7 & Juli & 2.900 .000 & 1.450 .000 \\
\hline 8 & Agustus & 2.950 .000 & 1.475 .000 \\
\hline 9 & September & 2.835 .000 & 1.417 .500 \\
\hline 10 & Oktober & 2.780 .000 & 1.390 .000 \\
\hline 11 & November & 2.570 .000 & 1.285 .000 \\
\hline 12 & Desember & 2.650 .000 & 1.325 .000 \\
\hline \multicolumn{2}{|c|}{ Jumlah } & 32.000 .000 & 16.000 .000 \\
\hline
\end{tabular}

Sumber: Data Olahan Penelitian (2019)

Setelah pelunasan $\mathrm{PPh}$ dalam tahun berjalan, selanjutnya menghitung $\mathrm{PPh}$ yang terutang pada akhir tahun pajak 2018 bagi dr. S dengan mengacu pada SPT Tahunan PPh Wajib Pajak orang pribadi (Formulir 1770), karena dr. S mempunyai penghasilan sehubungan dengan pekerjaan dari 2 pemberi kerja serta penghasilan dari pekerjaan bebas melalui praktik dokter. Ada beberapa tahap dalam menghitung PPh yang terutang pada akhir tahun pajak 2018 bagi dr. S, yaitu sebagai berikut. 
Tabel 9. Perhitungan PPh yang terutang pada akhir tahun pajak 2018 bagi dr. S

\begin{tabular}{|c|c|c|}
\hline Penghasilan neto dalam negeri dari pekerjaan bebas & Rp16.000.000 & {$[50 \% \times \mathrm{Rp} 32.000 .000]$} \\
\hline Penghasilan neto dalam negeri sehubungan dengan pekerjaan & Rp140.457.500 & [Rp106.257.500+Rp34.200.000] \\
\hline Penghasilan neto dalam negeri lainnya & - & \\
\hline Penghasilan neto luar negeri & - & \\
\hline Jumlah Penghasilan Neto & Rp156.457.500 & \\
\hline Zakat/sumbangan keagamaan yang bersifat wajib & - & \\
\hline Kompensasi Kerugian & - & \\
\hline $\begin{array}{l}\text { Jumlah Penghasilan Neto Setelah Pengurangan Zakat/Sumbangan } \\
\text { Keagamaan yang Bersifat Wajib dan Kompensasi Kerugian }\end{array}$ & Rp156.457.500 & \\
\hline Penghasilan Tidak Kena Pajak (K/3) & $\underline{\mathrm{Rp}}(72.000 .000)$ & \\
\hline Penghasilan Kena Pajak & Rp 84.457 .500 & \\
\hline Penghasilan Kena Pajak Pembulatan & Rp 84.457.000 & \\
\hline $\begin{array}{l}\text { Pajak Penghasilan Terutang (Tarif PPh Ps. } 17 \text { ayat (1) huruf a } x \\
\text { PKP) }\end{array}$ & Rp $\quad 7.668 .550$ & $\begin{array}{l}{[(5 \% \times \mathrm{Rp} 50.000 .000)+} \\
(15 \% \times \mathrm{Rp} 34.457 .000)]\end{array}$ \\
\hline Pengembalian/pengurangan $\mathrm{PPh}$ Pasal 24 yang telah dikreditkan & - & \\
\hline Jumlah Pajak Penghasilan Terutang & Rp 7.668 .550 & \\
\hline $\begin{array}{l}\mathrm{PPh} \text { yang dipotong/dipungut pihak lain, } \mathrm{PPh} \text { ditanggung Pemerintah, dan } \\
\mathrm{PPh} \text { yang dibayar/dipotong di Luar Negeri }\end{array}$ & $\underline{\operatorname{Rp} \quad(3.422 .850)}$ & [Rp1.712.850+Rp1.710.000] \\
\hline PPh yang harus dibayar sendiri/(PPh yang lebih dipotong/dipungut) & $\mathrm{Rp} \quad 4.245 .700$ & \\
\hline $\mathrm{PPh}$ yang dibayar sendiri ( $\mathrm{PPh}$ Pasal 25) & - & \\
\hline PPh yang kurang dibayar (PPh Pasal 29)/ & Rp $\quad 4.245 .700$ & \\
\hline PPh yang lebih dibayar (PPh Pasal 28 A)/ & - & \\
\hline PPh Nihil & - & \\
\hline Angsuran PPh Pasal 25 Tahun Pajak Berikutnya & 353.808 & {$[\mathrm{Rp} 4.245 .700 / 12]$} \\
\hline
\end{tabular}

Sumber: Data Olahan Penelitian (2019)

Tahap pertama adalah menghitung jumlah penghasilan neto dari seluruh penghasilan yang diterima oleh dr. S. Untuk perhitungan jumlah penghasilan neto dalam negeri dari pekerjaan bebas yang diperoleh dr. S pada tahun pajak 2018, dr. $\mathrm{S}$ diperbolehkan menggunakan Norma Penghitungan Penghasilan Neto (NPPN) dengan wajib melakukan pencatatan, karena jumlah penghasilan bruto dari pekerjaan bebas yang diperoleh dr. N pada tahun 2018 kurang dari Rp4,8 M yakni sebesar Rp32.000.000,00. Jumlah tersebut berasal dari penjumlahan penghasilan bruto praktik dokter di rumah dokter S selama tahun 2018. Dalam hal penggunaan NPPN di tahun pajak 2018, dr. S harus memberitahukan kepada Direktur Jenderal Pajak melalui penyampaian surat pemberitahuan penggunaan norma dalam jangka waktu 3 bulan pertama pada tahun pajak 2018, yaitu bulan Januari hingga Maret 2018. Untuk mendapatkan jumlah penghasilan neto dalam negeri dari pekerjaan bebas dihitung dengan cara mengalikan jumlah penghasilan bruto dari pekerjaan bebas yang diperoleh dr. S pada tahun 2018 sebesar Rp32.000.000,00 dengan persentase NPPN yang berlaku pada tahun pajak 2018 untuk jenis usaha dokter di wilayah Bandung sebesar 50\%, maka jumlahnya Rp16.000.000,00. Sedangkan, jumlah penghasilan neto dalam negeri sehubungan dengan pekerjaan yang diperoleh dr. S pada tahun pajak 2018 adalah Rp140.457.500,00 (Rp106.257.500,00+Rp34.200.000,00). Setelah mendapatkan jumlah penghasilan neto dalam negeri sehubungan dengan pekerjaan dan jumlah penghasilan neto 
dalam negeri dari pekerjaan bebas, kemudian jumlahkan agar mendapatkan jumlah penghasilan neto setahun, maka diperoleh jumlahnya sebesar Rp156.457.500,00.

Pada tahun 2018, dr. S tidak membayarkan zakat/sumbangan keagamaan yang bersifat wajib kepada badan amil zakat atau lembaga amil zakat yang dibentuk atau disahkan oleh Pemerintah sesuai dengan bukti setoran yang sah. Untuk kompensasi kerugian hanya akan terjadi bagi Wajib Pajak yang menyelenggarakan pembukuan karena pada pencatatan tidak ada kerugian fiskal. Bagi dr. S tidak ada kompensasi kerugian sebab menyelenggarakan pencatatan. Sehingga, jumlah penghasilan neto setahun setelah pengurangan zakat/sumbangan keagamaan yang bersifat wajib dan kompensasi kerugian sama dengan jumlah penghasilan neto setahun, yaitu Rp156.457.500,00.

Tahap selanjutnya adalah menghitung PKP sebagai dasar perhitungan $\mathrm{PPh}$ yang terutang pada akhir tahun pajak 2018 bagi dr. S, yaitu dengan cara mengurangi jumlah penghasilan neto setahun setelah pengurangan zakat/sumbangan keagamaan yang bersifat wajib dan kompensasi kerugian dengan besarnya PTKP. PTKP bagi dr. S adalah K/3. Besarnya jumlah PTKP per tahun untuk status K/3 pada tahun pajak 2018 adalah Rp72.000.000,00. Maka, besarnya PKP adalah Rp84.457.500,00.

Tahap terakhir yang harus dilakukan untuk memperoleh besarnya PPh yang terutang pada akhir tahun pajak 2018 bagi dr. S, yaitu mengalikan PKP dengan tarif PPh Pasal 17 ayat (1) huruf a UU PPh. Dalam penerapan tarif PPh tersebut, jumlah PKP dibulatkan ke bawah dalam ribuan rupiah penuh menjadi Rp84.457.000,00. Maka perhitungan $\mathrm{PPh}$ yang terutang pada akhir tahun pajak 2018 bagi dr. $\mathrm{N}$ :

$$
\begin{array}{ll}
\mathrm{Rp} 50.000 .000,00 \times 5 \% & =\mathrm{Rp} 2.500 .000,00 \\
\mathrm{Rp} 34.457 .000,00 \times 15 \% & =\mathrm{Rp} 5.168 .550,00+ \\
\mathrm{PPh} \text { yang terutang } & =\mathrm{Rp} 7.668 .550,00
\end{array}
$$

Di 2018, dr. S tidak menerima pengembalian atau pengurangan PPh Pasal 24 yang telah dikreditkan, maka jumlah PPh yang terutang tetap sebesar Rp7.668.550,00.

Untuk pelunasan PPh pada akhir tahun pajak, tidak hanya sampai mendapatkan jumlah $\mathrm{PPh}$ yang terutang saja, namun dr. S juga harus mengetahui $\mathrm{PPh}$ yang terutang pada akhir tahun pajak ini lebih kecil atau lebih besar atau sama dengan kredit pajak, yaitu dengan cara mengurangi jumlah PPh yang terutang pada akhir tahun pajak dengan kredit pajak dr. S. Kredit pajak bagi dr. S adalah PPh yang dipotong/dipungut pihak lain, $\mathrm{PPh}$ ditanggung Pemerintah, dan $\mathrm{PPh}$ yang $\begin{array}{lllll}\text { dibayar/dipotong } & \text { di } & \text { LN } & \text { sebesar } & \text { Rp3.422.850,00 }\end{array}$ (Rp1.712.850,00+Rp1.710.000,00). Maka, pada akhir tahun pajak 2018, dr. S mengalami PPh Kurang Bayar (PPh Pasal 29) sebesar Rp4.245.700,00. PPh 
kurang bayar ini wajib dilunasi oleh dr. S sebelum dr. S menyampaikan SPT Tahunan PPh Wajib Pajak orang pribadi (Formulir 1770) untuk tahun pajak 2018, paling lambat tanggal 31 Maret 2018. Untuk perhitungan angsuran PPh Pasal 25 tahun pajak 2019 didasarkan pada $\mathrm{PPh}$ yang harus dibayar sendiri/( $\mathrm{PPh}$ yang lebih dipotong/dipungut), yaitu Rp4.245.700,00 dibagi 12, maka besarnya Rp353.808,00.

\section{Persamaan Perlakuan Pajak Penghasilan Bagi Dokter Dengan Status Sebagai Pegawai Negeri dan Dokter Dengan Status Sebagai Pegawai Swasta}

Berikut ini persamaan perlakuan pajak penghasilan antara dokter dengan status sebagai pegawai negeri dan dokter dengan status sebagai pegawai swasta, yaitu.

1. Tidak dikenakan $\mathrm{PPh}$, jika memperoleh penghasilan yang dikecualikan dari objek $\mathrm{PPh}$, seperti harta hibahan; warisan; penggantian atau imbalan sehubungan dengan pekerjaan/jasa yang diterima dalam bentuk natura dan/atau kenikmatan dari Wajib Pajak atau Pemerintah; pembayaran asuransi kesehatan/asuransi kecelakaan/ jiwa/asuransi dwiguna/asuransi beasiswa dari perusahaan asuransi; bagian laba yang diperoleh anggota dari perseroan komanditer yang modalnya tidak terbagi atas saham-saham, persekutuan, perkumpulan, firma, dan kongsi, termasuk pemegang unit penyertaan kontrak investasi kolektif; beasiswa; bantuan atau santunan akibat bencana alam seperti gempa bumi, tsunami, gunung meletus, banjir, kekeringan, angin topan dan tanah longsor atau tertimpa kecelakaan, yang dibayarkan Badan Penyelenggara Jaminan Sosial.

2. Dikenakan perlakuan $\mathrm{PPh}$ Pasal 4 ayat (2) yang bersifat final, jika memperoleh penghasilan berupa bunga deposito dan tabungan serta diskonto SBI; bunga obligasi; bunga simpanan yang dibayarkan oleh koperasi yang didirikan di Indonesia kepada anggota koperasi orang pribadi; hadiah undian; penghasilan dari transaksi penjualan saham di bursa efek; penghasilan dari pengalihan hak atas tanah dan/atau bangunan; penghasilan dari persewaan tanah dan/atau bangunan; dan penghasilan dari usaha (selain pekerjaan bebas) dengan peredaran bruto kurang dari Rp4,8 M dalam 1 Tahun Pajak.

3. Dikenakan perlakuan PPh Pasal 17 ayat (2c) yang bersifat final, jika menerima dividen.

4. Dikenakan pemotongan $\mathrm{PPh}$ Pasal 21 yang bersifat final, jika menerima uang pesangon, uang manfaat pensiun, tunjangan hari tua, atau jaminan hari tua yang dibayarkan sekaligus.

5. Dikenakan pemotongan $\mathrm{PPh}$ Pasal 21 yang bersifat tidak final, jika memperoleh penghasilan sehubungan dengan pekerjaan menjadi pegawai tetap 
berupa penghasilan yang bersifat teratur dan tidak teratur. Persamaan ini, hanya pada sifat pengenaannya adalah tidak final, dan besarnya tarif pajak.

6. Dikenakan pemotongan PPh Pasal 21 yang bersifat tidak final, jika telah pensiun dan menerima uang pensiun secara teratur; menerima uang pesangon, uang manfaat pensiun, tunjangan hari tua, atau jaminan hari tua yang dibayarkan pada tahun ketiga dan tahun-tahun berikutnya; menerima imbalan kepada bukan pegawai yang bersifat berkesinambungan; memperoleh imbalan kepada bukan pegawai yang tidak bersifat berkesinambungan; memperoleh imbalan kepada peserta kegiatan.

7. Dikenakan pemungutan PPh Pasal 22 yang bersifat tidak final, jika terkait dengan kegiatan impor barang; pembelian barang oleh bendaharawan pemerintah; dan pembelian barang oleh badan usaha tertentu.

8. Dikenakan pemotongan PPh Pasal 23 yang bersifat tidak final, jika menerima royalti; serta penghasilan dari sewa dan penghasilan lain sehubungan dengan penggunaan harta, selain sewa dan penghasilan lain sehubungan dengan tanah dan/atau bangunan.

9. Dikenakan perlakuan PPh Pasal 24, jika menerima penghasilan yang diperoleh dari luar negeri.

10. Memiliki mekanisme perhitungan angsuran PPh Pasal 25 yang sama.

11. Memiliki mekanisme perhitungan PPh yang terutang pada akhir tahun pajak yang sama, juga sama pula perhitungan pelunasan $\mathrm{PPh}$ pada akhir tahun pajak.

12. Atas perolehan penghasilan dari pekerjaan bebas melalui praktik dokter yang jumlah peredaran brutonya kurang dari Rp4,8 M dalam satu tahun pajak, maka diperbolehkan menghitung penghasilan neto dalam negeri dari pekerjaan bebas menggunakan Norma Penghitungan Penghasilan Neto (NPPN) dengan menyelenggarakan pencatatan. Namun, jika peredaran brutonya sudah mencapai Rp 4,8 M atau lebih dalam satu tahun pajak, maka diwajibkan untuk menyelenggarakan pembukuan.

\section{Perbedaan Perlakuan Pajak Penghasilan Bagi Dokter Dengan Status Sebagai Pegawai Negeri dan Dokter Dengan Status Sebagai Pegawai Swasta}

Selain terdapat persamaan, juga terdapat perbedaan perlakuan perpajakan antara dokter dengan status sebagai pegawai negeri dan dokter dengan status sebagai pegawai swasta, yaitu sebagai berikut. 


\section{Tabel 10. Perbedaan Perlakuan Perpajakan Antara Dokter Dengan Status Sebagai Pegawai Negeri Dan Dokter Dengan Status Sebagai Pegawai Swasta}

\begin{tabular}{|c|c|c|}
\hline & Dokter dengan status pegawai negeri & \\
\hline \multirow{2}{*}{$\begin{array}{l}\text { Penghasilan } \\
\text { sehubungan } \\
\text { dengan pekerjaan } \\
\text { berupa } \\
\text { penghasilan yang } \\
\text { bersifat teratur } \\
\text { dan tidak teratur }\end{array}$} & $\begin{array}{l}\text { Dikenakan pemotongan } \mathrm{PPh} \text { Pasal } 21 \text { bagi } \\
\text { pegawai tetap yang bersifat tidak final dan } \\
\text { ditanggung oleh pemerintah atas beban APBN } \\
\text { atau APBD. }\end{array}$ & $\begin{array}{l}\text { Dikenakan pemotongan } \mathrm{PPh} \text { Pasal } 21 \text { bagi } \\
\text { pegawai tetap yang bersifat tidak final oleh } \\
\text { pemberi kerja dan tidak ditanggung } \\
\text { pemerintah. }\end{array}$ \\
\hline & $\begin{array}{l}\text { Bukti pemotongan PPh Pasal } 21 \text { bagi PNS atau } \\
\text { Anggota TNI atau Anggota POLRI atau Pejabat } \\
\text { Negara atau Pensiunannya (Formulir 1721-A2) } \\
\text { diberikan oleh bendahara pemerintah. }\end{array}$ & $\begin{array}{l}\text { Bukti pemotongan PPh Pasal } 21 \text { bagi Pegawai } \\
\text { Tetap atau Penerima Pensiun atau Tunjangan } \\
\text { Hari Tua/Jaminan Hari Tua Berkala (Formulir } \\
\text { 1721-A1) diberikan oleh pemberi kerja. }\end{array}$ \\
\hline \multirow{3}{*}{$\begin{array}{l}\text { Honorarium atau } \\
\text { imbalan lain } \\
\text { dengan nama } \\
\text { apapun yang } \\
\text { menjadi beban } \\
\text { APBN atau } \\
\text { APBD } \\
\text { (Honorarium dan } \\
\text { imbalan lain } \\
\text { sejenisnya) }\end{array}$} & $\begin{array}{l}\text { Dikenakan pemotongan PPh Pasal } 21 \text { yang } \\
\text { bersifat final. }\end{array}$ & $\begin{array}{l}\text { Dikenakan pemotongan PPh Pasal } 21 \text { bagi } \\
\text { pegawai tetap yang bersifat tidak final oleh } \\
\text { pemberi kerja. }\end{array}$ \\
\hline & $\begin{array}{l}\text { Mekanisme perhitungannya, yaitu dengan cara } \\
\text { mengalikan jumlah penghasilan bruto honorarium } \\
\text { atau imbalan lain setiap kali pembayaran dengan } \\
\text { besarnya tarif PPh Pasal } 21 \text { yang bersifat final } \\
\text { berdasarkan golongan kepangkatan bagi PNS, } \\
\text { anggota POLRI, anggota TNI. Maka, jumlah } \\
\text { honorarium atau imbalan lain sejenisnya tersebut } \\
\text { tidak dimasukkan dalam perhitungan jumlah } \\
\text { penghasilan bruto yang diperoleh pegawai tetap } \\
\text { sehubungan dengan pekerjaan sebagai dasar } \\
\text { perhitungan Penghasilan Kena Pajak. }\end{array}$ & $\begin{array}{l}\text { Mekanisme perhitungannya, yaitu dengan cara } \\
\text { mengalikan Penghasilan Kena Pajak bagi } \\
\text { pegawai tetap dengan tarif } \mathrm{PPh} \text { Pasal } 17 \text { ayat } \\
\text { (1) huruf a Undang-Undang PPh. Maka, } \\
\text { jumlah honorarium atau imbalan lain sejenisnya } \\
\text { tersebut dimasukkan dalam perhitungan jumlah } \\
\text { penghasilan bruto yang diperoleh pegawai } \\
\text { tetap sehubungan dengan pekerjaan sebagai } \\
\text { dasar perhitungan Penghasilan Kena Pajak. }\end{array}$ \\
\hline & $\begin{array}{l}\text { Bukti pemotongan } \mathrm{PPh} \text { Pasal } 21 \text { Final (Formulir } \\
\text { 1721-VII) diberikan oleh bendahara pemerintah. } \\
\text { Bukti pemotongan ini berarti terpisah dengan } \\
\text { pemotongan PPh Pasal } 21 \text { atas penghasilan } \\
\text { sehubungan dengan pekerjaan berupa } \\
\text { penghasilan yang bersifat teratur dan tidak } \\
\text { teratur. }\end{array}$ & $\begin{array}{l}\text { Bukti pemotongan PPh Pasal } 21 \text { bagi Pegawai } \\
\text { Tetap atau Penerima Pensiun atau Tunjangan } \\
\text { Hari Tua/Jaminan Hari Tua Berkala (Formulir } \\
\text { 1721-A1) diberikan oleh pemberi kerja. } \\
\text { Maka, pemotongan penghasilan ini menyatu } \\
\text { dengan pemotongan PPh Pasal } 21 \text { atas } \\
\text { penghasilan sehubungan dengan pekerjaan } \\
\text { berupa penghasilan yang bersifat teratur dan } \\
\text { tidak teratur. }\end{array}$ \\
\hline
\end{tabular}

Sumber: Hasil olahan peneliti (2019)

\section{KESIMPULAN}

Atas penghasilan yang diperoleh, dokter dengan status sebagai pegawai negeri atau pegawai swasta dapat dikenakan $\mathrm{PPh}$ yang bersifat final atau tidak final atau tidak dikenakan $\mathrm{PPh}$. Dengan status kepegawaian yang berbeda antara pegawai negeri dan pegawai swasta, maka terdapat persamaan maupun perbedaan dalam hal perlakuan $\mathrm{PPh}$. Dalam praktiknya terlihat pada perlakuan perpajakan dr. $\mathrm{N}$ selaku dokter dengan status pegawai negeri juga dr. S selaku dokter dengan status pegawai swasta. Maka, sebagai wajib pajak seorang dokter sebaiknya memiliki pengetahuan dan kemauan untuk melaksanakan kewajiban perpajakannya sesuai dengan peraturan perpajakan yang berlaku meskipun tidak berlatar belakang 
pendidikan perpajakan atau berprofesi di bidang perpajakan. Wajib pajak sebaiknya mempelajari peraturan mengenai perpajakan, baik sendiri ataupun berkonsultasi kepada konsultan pajak atau Account Representative-nya di Kantor Pelayanan Pajak tempat Wajib Pajak terdaftar. Hal ini dimaksudkan untuk mendukung berjalannya self assessment system di Indonesia, sehingga mampu meningkatkan penerimaan negara.

\section{REFERENSI}

Indrawan, Rizki, Bani Binekas. (2018). Pemahaman Pajak dan Pengetahuan Pajak Terhadap Kepatuhan Wajib Pajak UKM. Jurnal Riset Akuntansi Dan Keuangan, Vol. 6, No. 3: 419-428.

Kementerian Keuangan. (2019). Laporan Keuangan Pemerintah Pusat Tahun 2018 Audited. Jakarta: Pemerintah Republik Indonesia.

Mardiasmo. (2018). Edisi 19. Perpajakan-Edisi Terbaru 2018. Yogyakarta: Andi.

Meliala, T.S. dan Francisca Widianti Oetomo. (2012). Edisi 7. Perpajakan dan Akuntansi Pajak. Jakarta: Semesta Media.

Sekaran, Uma dan Roger Bougie. (2016). Seventh edition. Research Methods for Business. United Kingdom: WILEY.

Undang-Undang Nomor 36 Tahun 2014 tentang Tenaga Kesehatan.

Undang-Undang Nomor 16 Tahun 2009 tentang Penetapan Peraturan Pemerintah Pengganti Undang-Undang Nomor 5 Tahun 2008 Tentang Perubahan Keempat Atas Undang-Undang Nomor 6 Tahun 1983 Tentang Ketentuan Umum Dan Tata Cara Perpajakan Menjadi Undang-Undang.

Undang-Undang Nomor 36 Tahun 2008 tentang Perubahan Keempat Atas Undang-Undang Nomor 7 Tahun 1983 Tentang Pajak Penghasilan.

Peraturan Pemerintah Nomor 80 Tahun 2010 tentang Tarif Pemotongan Dan Pengenaan Pajak Penghasilan Pasal 21 Atas Penghasilan Yang Menjadi Beban Anggaran Pendapatan Dan Belanja Negara Atau Anggaran Pendapatan Dan Belanja Daerah.

Peraturan Pemerintah Nomor 68 Tahun 2009 tentang Tarif Pajak Penghasilan Pasal 21 Atas Penghasilan Berupa Uang Pesangon, Uang Manfaat Pensiun, Tunjangan Hari Tua, Dan Jaminan Hari Tua Yang Dibayarkan Sekaligus.

Peraturan Pemerintah Nomor 123 Tahun 2015 tentang Perubahan Atas Peraturan Pemerintah Nomor 131 Tahun 2000 Tentang Pajak Penghasilan Atas Bunga Deposito Dan Tabungan Serta Diskonto Sertifikat Bank Indonesia. 
October, 2020

Peraturan Pemerintah Nomor 100 Tahun 2013 tentang Perubahan Atas Peraturan Pemerintah Nomor 16 Tahun 2009 Tentang Pajak Penghasilan Atas Penghasilan Berupa Bunga Obligasi.

Peraturan Pemerintah Nomor 15 Tahun 2009 tentang Pajak Penghasilan Atas Bunga Simpanan Yang Dibayarkan Oleh Koperasi Kepada Anggota Koperasi Orang Pribadi.

Peraturan Pemerintah Nomor 132 Tahun 2000 tentang Pajak Penghasilan Atas Hadiah Undian.

Peraturan Pemerintah Nomor 14 Tahun 1997 tentang Perubahan Atas Peraturan Pemerintah Nomor 41 Tahun 1994 Tentang Pajak Penghasilan Atas Penghasilan Dari Transaksi Penjualan Saham Di Bursa Efek.

Peraturan Pemerintah Nomor 34 Tahun 2016 tentang Pajak Penghasilan Atas Penghasilan Dari Pengalihan Hak Atas Tanah Dan/Atau Bangunan, Dan Perjanjian Pengikatan Jual Beli Atas Tanah Dan/Atau Bangunan Beserta Perubahannya.

Peraturan Pemerintah Nomor 34 Tahun 2017 tentang Pajak Penghasilan Atas Penghasilan Dari Persewaan Tanah Dan/Atau Bangunan.

Peraturan Pemerintah Nomor 23 Tahun 2018 tentang Pajak Penghasilan Atas Penghasilan Dari Usaha Yang Diterima Atau Diperoleh Wajib Pajak Yang Memiliki Peredaran Bruto Tertentu.

Peraturan Pemerintah Nomor 19 Tahun 2009 tentang Pajak Penghasilan Atas Dividen Yang Diterima Atau Diperoleh Wajib Pajak Orang Pribadi Dalam Negeri.

Peraturan Menteri Keuangan Nomor 247/PMK.03/2008 tentang Bantuan Atau Santunan Yang Dibayarkan Oleh Badan Penyelenggara Jaminan Sosial Kepada Wajib Pajak Tertentu Yang Dikecualikan Dari Objek Pajak Penghasilan.

Peraturan Menteri Keuangan Nomor 245/PMK.03/2008 tentang Badan-Badan Dan Orang Pribadi Yang Menjalankan Usaha Mikro Dan Kecil Yang Menerima Harta Hibah, Bantuan, Atau Sumbangan Yang Tidak Termasuk Sebagai Objek Pajak Penghasilan.

Peraturan Menteri Keuangan Nomor 154/PMK.03/2009 tentang Perubahan Atas Peraturan Menteri Keuangan Nomor 246/PMK.03/2008 Tentang Beasiswa Yang Dikecualikan Dari Objek Pajak Penghasilan.

Peraturan Menteri Keuangan Nomor 101/PMK.010/2016 tentang Penyesuaian Besarnya Penghasilan Tidak Kena Pajak. 
Peraturan Menteri Keuangan Nomor 262/PMK.03/2010 tentang Tata Cara Pemotongan Pajak Penghasilan Pasal 21 Bagi Pejabat Negara, PNS, Anggota TNI, Anggota POLRI, Dan Pensiunannya Atas Penghasilan Yang Menjadi Beban Anggaran Pendapatan Dan Belanja Negara Atau Anggaran Pendapatan Dan Belanja Daerah.

Peraturan Menteri Keuangan Nomor 16/PMK.03/2010 tentang Tata Cara Pemotongan Pajak Penghasilan Pasal 21 Atas Penghasilan Berupa Uang Pesangon, Uang Manfaat Pensiun, Tunjangan Hari Tua, Dan Jaminan Hari Tua Yang Dibayarkan Sekaligus.

Peraturan Menteri Keuangan Nomor 110/PMK.010/2018 tentang Perubahan Atas

Peraturan Menteri Keuangan Nomor 34/PMK.10/2017 Tentang Pemungutan Pajak Penghasilan Pasal 22 Sehubungan Dengan Pembayaran Atas Penyerahan Barang Dan Kegiatan Di Bidang Impor Atau Kegiatan Usaha Di Bidang Lain.

Peraturan Menteri Keuangan Nomor 111/PMK.03/2010 tentang Tata Cara Pemotongan, Penyetoran, Dan Pelaporan Pajak Penghasilan Atas Dividen Yang Diterima Atau Diperoleh Wajib Pajak Orang Pribadi Dalam Negeri.

Peraturan Menteri Keuangan Nomor 192/PMK.03/2018 tentang Pelaksanaan Pengkreditan Pajak Atas Penghasilan Dari Luar Negeri.

Peraturan Direktur Jenderal Pajak Nomor PER-16/PJ/2016 tentang Pedoman Teknis Tata Cara Pemotongan, Penyetoran, Dan Pelaporan Pajak Penghasilan Pasal 21 Dan/Atau Pajak Penghasilan Pasal 26 Sehubungan Dengan Pekerjaan, Jasa, Dan Kegiatan Orang Pribadi.

Peraturan Direktur Jenderal Pajak Nomor: PER-4/PJ/2009 tentang Petunjuk Pelaksanaan Pencatatan Bagi Wajib Pajak Orang Pribadi.

Peraturan Direktur Jenderal Pajak Nomor PER-17/PJ./2015 tentang Norma Penghitungan Penghasilan Neto.

Surat Edaran Direktur Jenderal Pajak Nomor SE-51/PJ.43/1995 tentang Pemotongan PPh Pasal 21 Atas Honorarium Dokter Yang Praktek Di Rumah Sakit (Seri PPh Pasal 21 Nomor 9). 